\title{
Interactive comment on "Ozone measurement practice in the laboratory using Schönbein's method" by Ignacio Arturo Ramirez-Gonzalez et al.
}

\section{Anonymous Referee \#1}

Received and published: 10 August 2019

\section{General comments}

I am not commenting on the scientific content of the method presented, as it is not my field. From a scientific communication and science outreach perspective, various aspects remain unclear; a specific reason for choosing to use the 19th century method is implied but not elaborated on, the presentation of the method of delivery is somewhat jumbled and I see no evidence that the approach itself is effective beyond the authors asserting that it was (and which they attribute to the students and teachers involved rather than their own approach) or that it has been properly evaluated in this respect. There is certainly potential here to produce interesting information about the efficacy of the technique in communicating this topic to students, but much more information and a thorough evaluation of this is needed. Supporting information from the literature 
around the value of such activities (e.g. raising science capital) could also be included. Specific comments

These are given in the attached file.

Technical comments

The general English needs some improvement throughout.

Interactive

comment

Please also note the supplement to this comment:

https://www.geosci-commun-discuss.net/gc-2019-12/gc-2019-12-RC1-supplement.pdf

Interactive comment on Geosci. Commun. Discuss., https://doi.org/10.5194/gc-2019-12, 2019. 